https://doi.org/10.11646/palaeoentomology.4.4.3

http://zoobank.org/urn:lsid:zoobank.org:pub:35681682-B272-4FA7-8C38-F07CC81AC31F

\title{
Fossil insects 10 years after the Geological Conservation Review (Great Britain)
}

\author{
ED JARZEMBOWSKI ${ }^{1,2}$

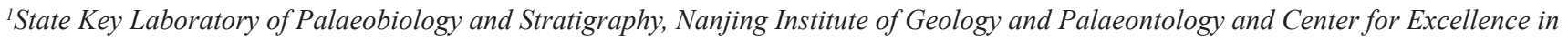 \\ Life and Paleoenvironment, Chinese Academy of Sciences, Nanjing 210008, China \\ ${ }^{2}$ Department of Earth Sciences, The Natural History Museum, Cromwell Road, London SW7 5BD, UK \\ ="jarzembowski2@live.co.uk; @ ittps://orcid.org/0000-0001-8772-4375
}

At the third congress of the I.P.S. (International Palaeoentomological Society) in Beijing (2010), Professor Dong Ren, conference organiser, was presented with an author's copy of the arthropod volume of the Geological Conservation Review of Great Britain, which included fossil insects, and had just been published (Jarzembowski et al., 2010). The purpose of the review, which commenced in the last century before the founding of I.P.S., was essentially to select and document the key sites of British geology, geomorphology and palaeontology with view to geoheritage conservation-including palaeoentomology. The results were collated and published in a series of volumes and, as it subsequently transpired, the arthropod volume was the last one (number 35). The insect part (written by the current author) and other arthropods (by Derek Siveter and Paul Selden) were augmented by general geology and palaeontology contributed by Douglas Palmer. A planned volume with relevant Lower Cretaceous (Wealden) geology was eventually produced instead as a short series of papers by the Geologists' Association of London (Radley \& Allen, 2012b). Geoconservation has featured periodically on the I.P.S. agenda and this paper reflects on the legacy of the GCR study, a decade later, and over a generation after its initiation.

\section{The sites}

From over 180 sites considered in the British Isles, nineteen were eventually selected to represent GB palaeoentomology - 17 in England and two in Scotland, 96\% of the fossil-insect species being found in England. Subsequently plotted on a map, they cluster in the south of England (Fig. 1). Two factors influenced this pattern. Firstly, the insect record only commences in the late Palaeozoic and older rocks characterise significant parts of the north and west of Britain (Toghill, 2000). Secondly, in a temperate climate, inland exposures rely much on being maintained by human activity which, in turn, is related to the vagaries of economic activity; at time of writing, only a single quarry selected is still active (Fig. 4D). In contrast, coastal exposures in 'soft' rocks prone to erosion have fared better, especially along the Channel coast (Fig. 4C). The scientific interest of these sites is, however, not limited to their availability for fieldwork and collecting; research on existing collections has also continued, underling the importance of museums, and this is summarised below. Inevitably, some new sites worthy of mention have emerged since the original review. These include the discovery of Early Cretaceous amber with some insect inclusions on the south coast of the Isle of Wight (Perkovsky et al., 2021), which would supplement the Paleogene sites already recognised in the north of the island. Also, the discovery of an Early Cretaceous indusifauna in the classical Wealden section at Hastings, East Sussex (Jarzembowski et al., 2016) enriches the fluvial geology exposed in the town's dominating East Cliff (Radley \& Allen, 2012a). These finds add to our growing knowledge of the Cretaceous, longer in duration than the entire Cenozoic, and one of the three priority periods for insect palaeontology recognised during the review (Jarzembowski, 1990; the other two-Middle Devonian-Mississippian and Tertiary are discussed below).

\section{Research and key works}

The most useful general book on fossil insects published in the UK during the past decade was by Penney \& Jepson (2014). Whilst new palaeoentomological discoveries and phylogenies continue to appear every year, the Scottish village of Rhynie is still associated with finds of the earliest hexapods; it was duly visited during the seventh I.P.S. congress (2016). The outcrop is protected under pasture and finding Early Devonian microarthropods there (in cherty deposits of hydrothermal origin) is no 


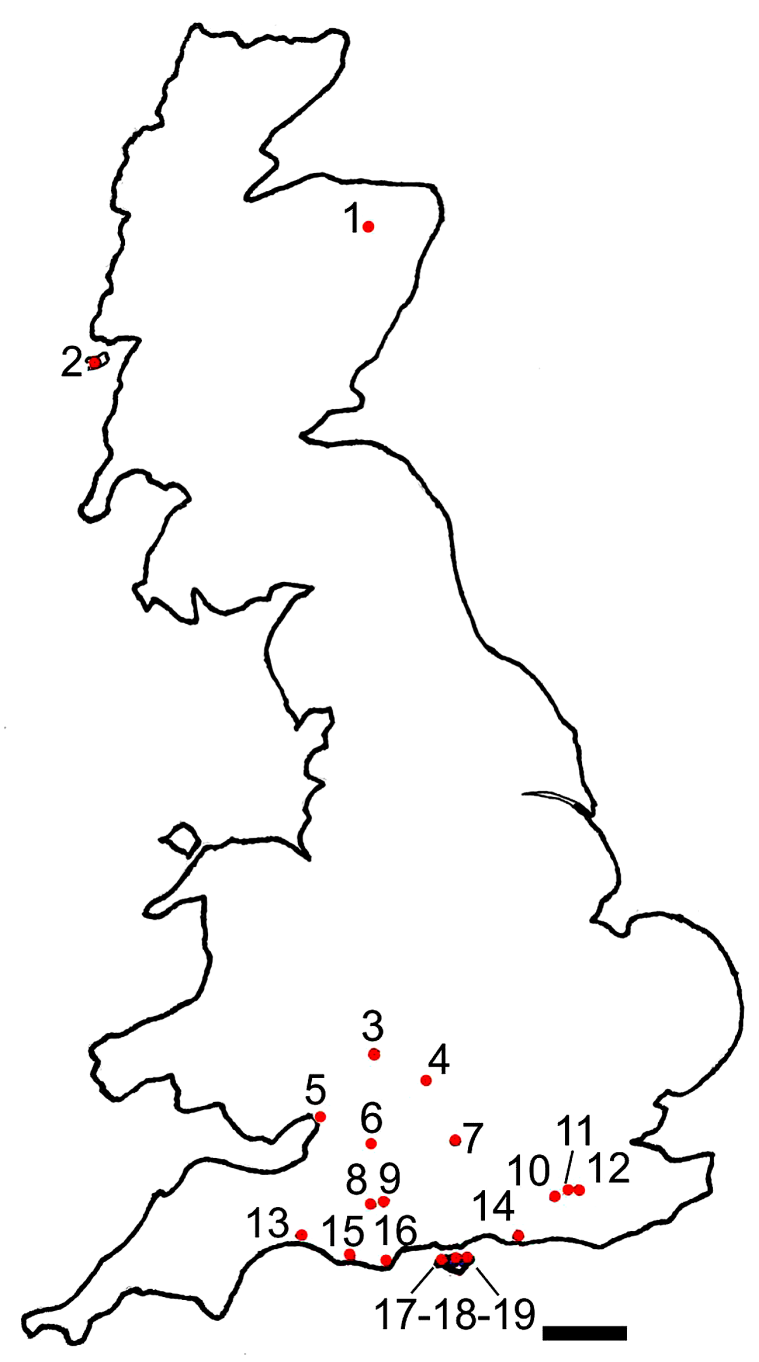

FIGURE 1. General location map of GB key palaeoentomology sites and county or equivalent: 1, Rhynie, Aberdeenshire; 2, Ardtun, Strathclyde; 3, Dumbleton and Alderton, Gloucestershire; 4, Stonesfield, Oxfordshire; 5, Aust Cliff, now in S. Gloucestershire; 6, Writhlington now in Bath \& N. E. Somerset; 7, Cold Ash, Berkshire; 8, Teffont Evias, Wiltshire; 9, Dinton, Wilts; 10, Smokejacks, Surrey; 11, Auclaye, Surrey; 12, Clockhouse, Surrey; 13, Charmouth, Dorset; 14, Bognor Regis, W. Sussex; 15, Poxwell, Dorset; 16, Durlston Bay, Dorset; 17, Bouldnor, Isle of Wight; 18, Gurnard, I. o. W.; 19, St Helens, I. o. W. Scale approximately $50 \mathrm{~km}$. 1, 6 Palaeozoic (late); 3-5, 813, 15, 16, Mesozoic; 2, 7, 14, 17-19, Cenozoic (Tertiary).

easy task. The historic collection of Rhyniella praecursor Hirst \& Maulik, 1926 has not been added to recently and this $1.5 \mathrm{~mm}$-long collembolan is restored herein (Fig. 2). The associated Rhyniognatha hirsti Tillyard, 1928 is now, however, considered a myriapod and not a hexapod (Haug \& Haug, 2017). This is in contrast to Leverhulmia mariae Anderson \& Trewin, 2003, originally proposed as a myriapod, then a stem hexapod (Fayers \& Trewin, 2005).

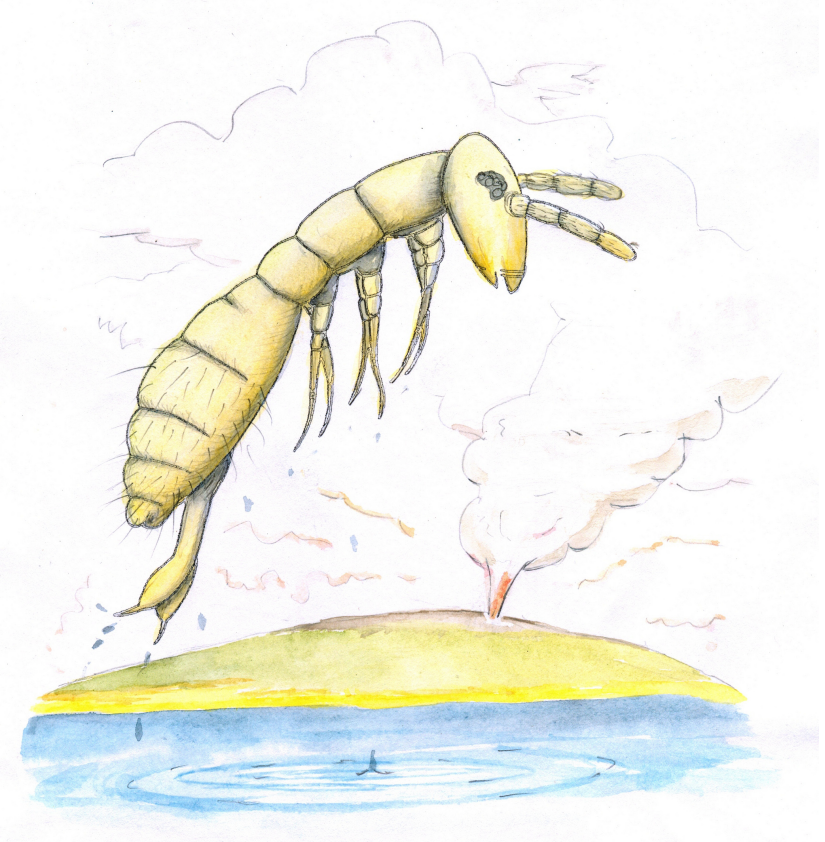

FIGURE 2. Fish-eye view of a springing Rhyniella praecursor Hirst \& Maulik, 1926; artistic reconstruction by Brigid Jarzembowski.

The landscape of the English and Scottish midlands and South Wales (De Cymru) was once dotted with coal mines in Pennsylvanian strata, but these have mainly closed. The reworking of a deep-mine colliery tip (spoil heap) near the village of Lower Writhlington (formerly in County Avon) in the last century yielded multiple fossil insects and abundant plants (Jarzembowski, 2018). Work on the fossil arthropods found there has continued up to the present day (Selden, 2021). Outreach is now considered an essential ingredient of UK science and Writhlington provided a historic opportunity (Fig. 4B).

The Mesozoic and Cenozoic GCR sites are in lowland England, with the exception of Ardtun (Àird Tunna) on the coast of the Isle of Mull, in the tertiary volcanic province of Scotland. This Paleocene locality was not reinvestigated for logistic reasons, but the insects found there are still relevant, e.g., Kania et al. (2015). The Mesozoic sites are in two main groups: Uppermost Triassic and Lower Jurassic plus Uppermost Jurassic and pre-Albian Lower Cretaceous, with the exception of Stonesfield in the Middle Jurassic. This village, not very far from Oxford, is historically renowned for mining roofing slate (Fig. 4A). Actually a fissile sandstone (or limestone), it was used by the university colleges. Celebrated early fossils found there included an alleged Jurassic butterfly (actually a palaeontinid hemipteran), although butterflies are known from the British Eocene (Fig. 3). The U. Triassic/ L. Jurassic sites are in the west of England and include estuarine and coastal cliff sections (Aust and Charmouth 


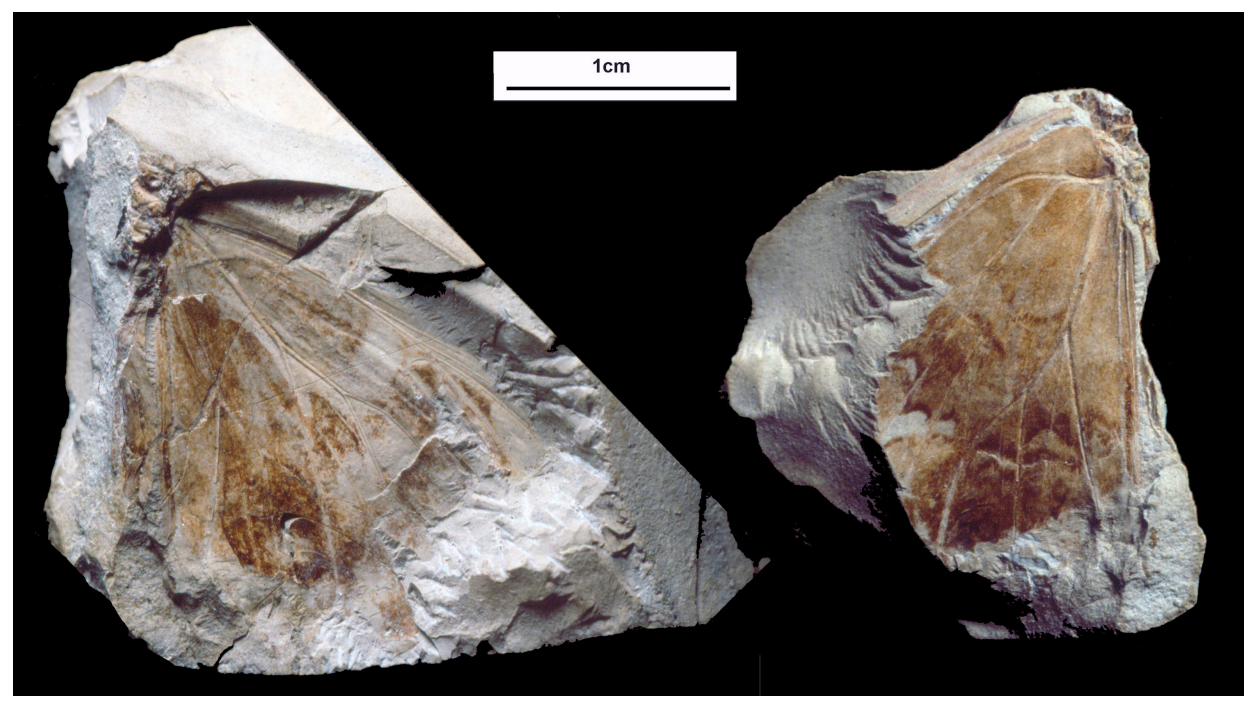

FIGURE 3. Nyphalites zeuneri Jarzembowski, 1980, holotype (NHM UK I 10384), Insect Bed (Bembridge Marls).
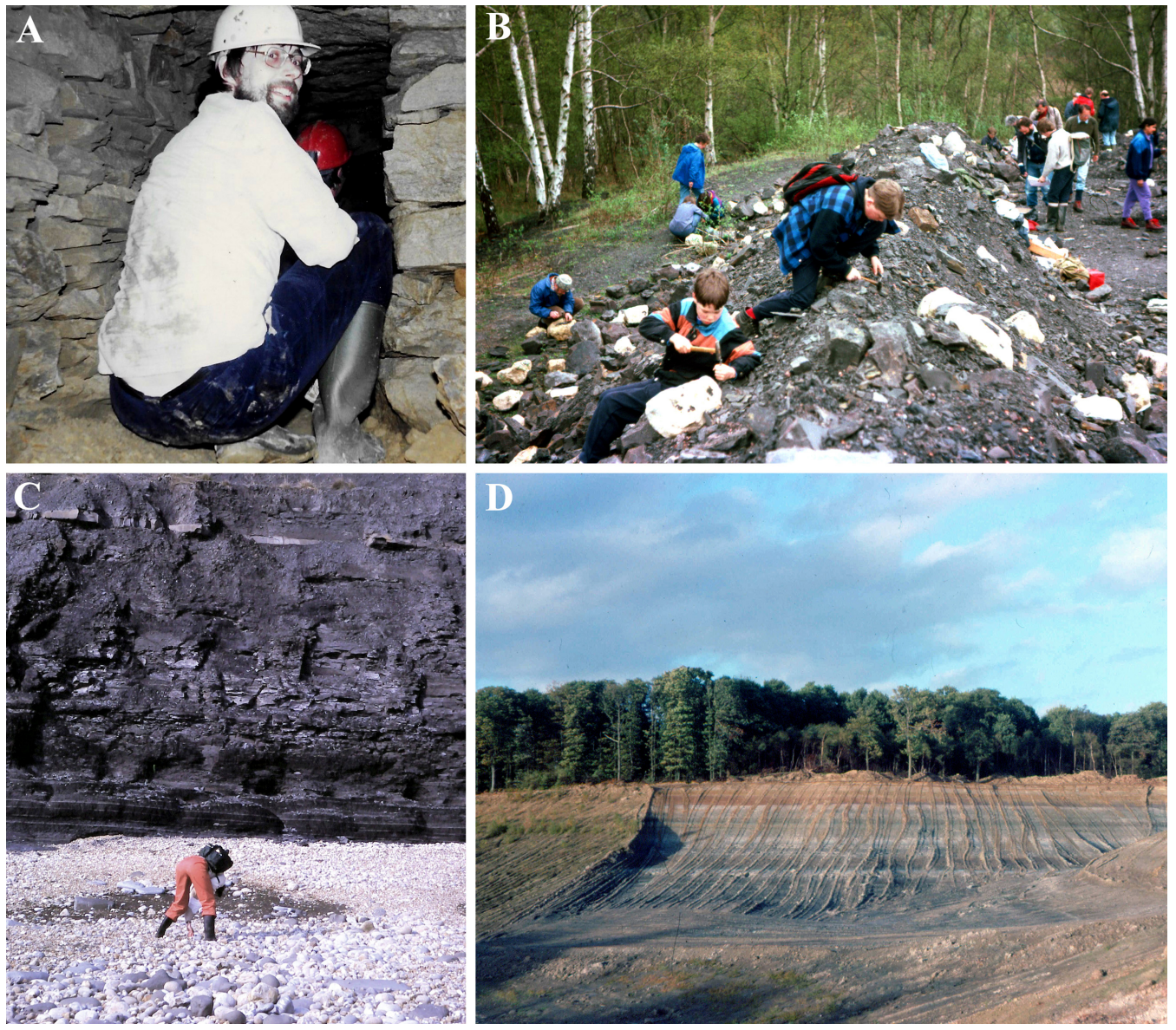

FIGURE 4. Fossil sites mentioned. A, Old tilestone working, Stonesfield, Oxfordshire (EJ for scale). B, Fossil collecting at the Writhlington rock store in the 1980s; insects occur in grey roof shales, mixed with some white blocks of local oolitic limestone. C, Coastal cliffs in the lower Lias Group, Charmouth, Dorset; insect remains occur in some of the limestone beds, pieces of which may be usefully searched on the beach. D, N.E. face in the upper Weald Clay Formation of Smokejacks brickworks, Surrey; insect remains occur in courses of sideritic concretions too small to see clearly in the photo.

respectively) as well as old inland exposures (Alderton and Dumbleton; these have been augmented recently by urban excavations in Ilminster, Somerset: Williams et al., 2015). Charmouth (Lower Jurassic), like the younger Durlston Bay (Uppermost Jurassic-Earliest Cretaceous), are part of the much-visited Jurassic Coast World Heritage Site. The older (Liassic) entomofauna there was summarised by Ross (2010) contemporary with the GCR volume; the palaeoecology was considered subsequently by Coram (2014). The younger (Purbeck) fauna, including inland 

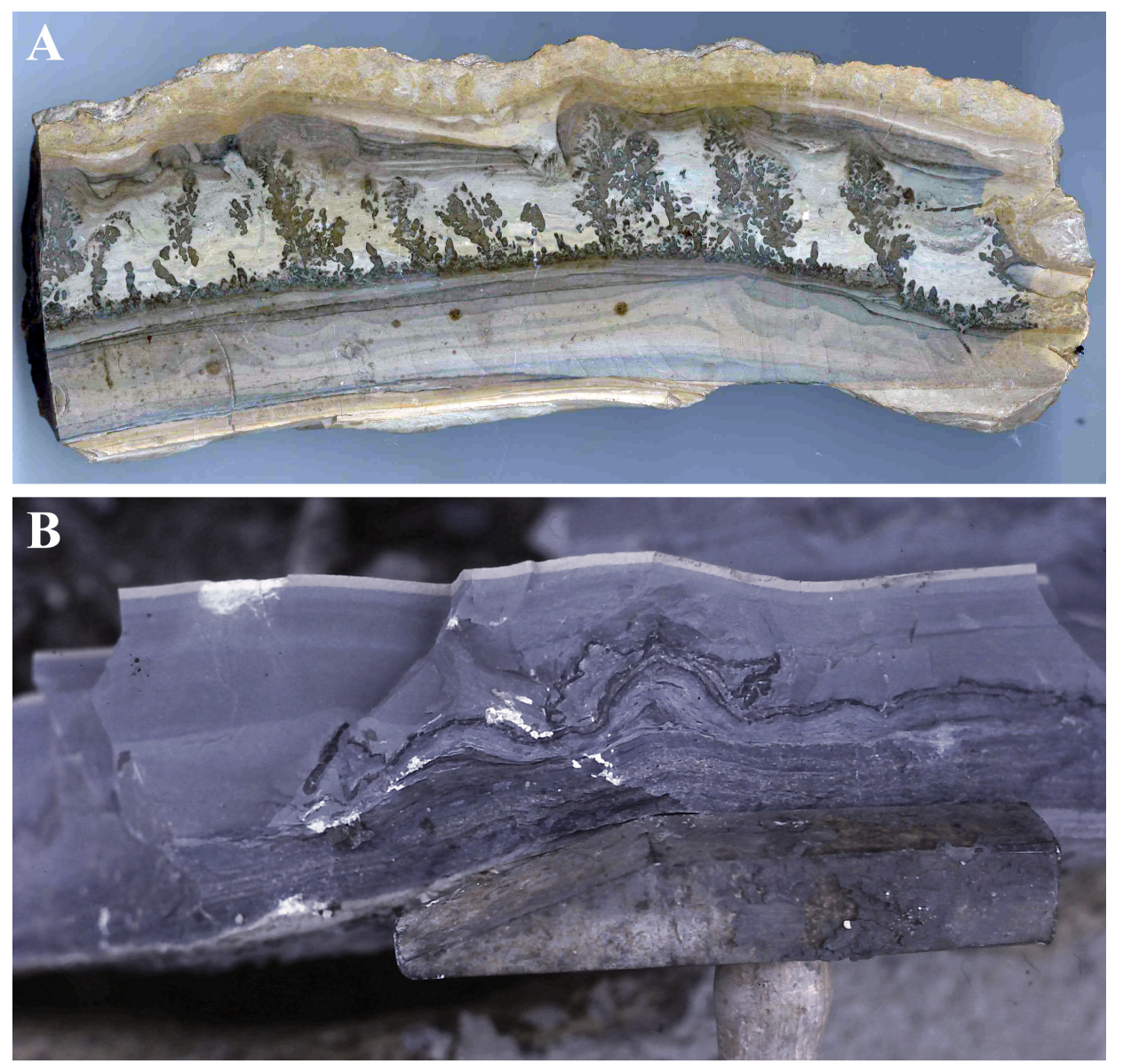

FIGURE 5. Sedimentary parallelism in British fossil-insect lithologies. A, Cotham Marble (actually limestone), Penarth Group, Aust Cliff (ornamental piece, $7.2 \mathrm{~cm}$ thick). B, stromatolitic limestone (microbialite) in middle Purbeck, Durlston Bay (Clements' Bed $175,1.13 \mathrm{~kg}$ geological hammer for scale, head $2.8 \mathrm{~cm}$ wide).

sites (Poxwell, Teffont and Dinton), is largely covered in a comprehensive book by Coram \& Jepson (2012). New fossil insects are still to be found, especially on the coast, and due to the popularity of 'fossiling' in the Lias, research papers may appear in unusual places not requiring specimen deposition (Bechly, 2018). The local awareness, however, is such that even road works may be investigated and finds subsequently formally described (Tihelka, 2019).

In S. and S. E. England, Early Cretaceous insect fossils occur in the Wealden Group (Jarzembowski, 2011; Ross, 2011), especially in the Weald Clay Formation of S. Surrey; they occur in sideritic and phosphatic concretions (Smokejacks and Auclaye brickworks respectively), or in distinctive scour fills (at the Clockhouse brickworks). Of these sites, only Smokejacks is still a working pit, although some new Wealden coastal localities are available, including one mentioned above. New finds continue to be made, last summarised by Austen \& Batten (2018). Annual updates appear in the G. A. Magazine and Hastings \& District Geological Society Journal, ideally followed by original research papers, e.g., Li et al. (2021). Insect remains may be accompanied by other arthropods (non-marine crustaceans) and an early amphipod was described recently from the now former Clockhouse brickworks (Jarzembowski et al., 2020).

The most productive insect-bearing horizon in the British tertiary, the Insect Bed/Limestone (Bembridge Marls), near Gurnard in the Isle of Wight, is thought to have been discovered originally on account of lithological similarity with beds in the middle Purbeck, across the Solent in Durlston Bay (Fig. 5B). In fact, the latter also shows some lithological similarity with the insect-bearing Uppermost Triassic at Aust (Fig. 5A). The eastern outcrop of this Tertiary Insect Bed (of Eocene age) at St Helens in the Isle of Wight, was also selected in the GCR partly because of its inclusion of the only British Cenozoic record of a spinicaudatan crustacean. Another of the three priorities for insect palaeontology referred to in the section above was the need for specialist attention on classical tertiary faunas in the light of modern entomological advances. A welcome major revision of the Insect Bed biota, involving a number of I.P.S. members since the last decade, has appeared in two volumes of the Earth and Environmental Science Transactions of the Royal Society of Edinburgh (parts 3/4 in vols 104 (2014) and 
110 (2019)). A final (palaeoenvironmental) paper is in preparation (Dr A. J. Ross, pers. comm., 2019).

Regarding other British Paleogene sites, Cold Ash in Berkshire was selected for its insect ichnofossils, but the quarry is now inactive. Ichnological interest has since shifted from Paleocene plants there to Eocene paludal palaeosols as in the Bembridge Limestone Formation, subjacent to the Bembridge Marls (Genise, 2016). Bognor, also Eocene, was chosen for its unusual pyritised insects (especially Coleoptera), but new finds are dependent on the winnowing action of the sea at this coastal locality, and none have been reported recently (Bone, 2013). Finally, Bouldnor in the I. o. W. produced the youngest British fossil insect assemblage (Oligocene), there being essentially a gap in the record until the Quaternary, which was not included in the GCR, being often considered as subfossil.

\section{Discussion}

Ten years after the GCR volume, new fossil insect species are being found annually in Britain, new records are being made (up to ordinal level), and even new localities are sometimes discovered. Whilst fine lacustrine deposits are the exception, insect remains can be locally common, even preserving microscopic detail due to mineralisation. Fossil gaps remain in the Permian and Neogene, and are possibly unavoidable due to Permo-Triassic aridisation and the Alpine orogeny respectively. Two general palaeoentomological priorities, nevertheless, have been met via the focus on the Lower Cretaceous (Purbeck/ Wealden) and co-operative study (involving multiple I.P.S. members) of the late Eocene entomofauna of the Isle of Wight. The third general priority, search for Late Devonian/Early Carboniferous (Mississippian) insects, has been less successful, although further afield, the Lower Pennsylvanian of County Clare (Contae an Chláir) in Ireland (Éire/Airlann) could contain their close relatives (Jarzembowski, 2016).

In the past decade, I.P.S. has lent its support to the successful palaeoconservation of McAbe in British Columbia (Dr Bruce Archibald, unpublished conference report, 2013), a world-class Eocene network site in the Okanagan Highlands. In the UK, geology and palaeontology is combined with wildlife and the rural landscape (but not archaeology) for conservation purposes. Palaeoentomology thus provides a deep-time dimension to insect natural history, spanning $>400 \mathrm{Ma}$. The entomology, climate and ecology of embryonic Britain differed profoundly from today. British fossil insects date from thermal maxima before the ice ageoften considered the historical cut-off for recent fauna.
Butterflies and ants, bees and social wasps only appeared here in the Eocene, alongside the last native archaic beetles, and accompanied by termites, now locally extinct. The latter made their debut in the Wealden alongside cockroaches and dragonflies, which were systematically more diverse than they are today. The British Mesozoic entomofauna pre-dates the ecological dominance of angiosperms, Carboniferous archaic dragonflies were associated with tropical lycopsid forests, and Devonian springtails frequented hot-spring pools. The earliest hexapods pre-dated both flying vertebrates and insects, and even familiar living orders, such as Neuroptera (lacewings), have changed composition over time, including a British nemopterid in the Paleogene, and domination by psychopsids in the Cretaceous. As late as the Pleistocene, the UK entomofauna still included exotic species (e.g., Tibetan dung beetle). Fossils of early highest Diptera, however, are still elusive and hundreds of British fossil insect species await formal description to augment the ca. 1,250 so far. There is thus much scope for the professional and amateur in discovering and advancing British palaeoentomology and, with international cooperation, contributing to global geoheritage. As the climate change agenda is rolled forward, fossil insects show that little things matter too, and that the past can provide a key to the present.

\section{Acknowledgements}

My thanks to Fred Clouter (Minster, UK) for assistance with scanned images and the editor and two referees for their time and comments. This is a Leverhulme Emeritus Fellowship contribution.

\section{References}

Anderson, L.I. \& Trewin, N.H. (2003) An Early Devonian arthropod fauna from the Windyfield chert, Aberdeenshire, Scotland. Palaeontology, 46, 467-509. https://doi.org/10.1111/1475-4983.00308

Austen, P.A. \& Batten, D.J. (2018) English Wealden fossils: an update. Proceedings of the Geologists' Association, 129, 171-201.

https://doi.org/10.1016/j.pgeola.2018.02.007

Bechly, G. (2018) Chrismooreia michaelbehei gen. et sp. nov. (Insecta: Odonata: Asiopteridae), a new fossil damseldragonfly from the Early Jurassic of England. BIO-Complexity, 2018 (1), 1-10. https://doi.org/10.5048/BIO-C.2018.1

Bone, D. (2013) The fossil beetles of Bognor Regis, West Sussex. Deposits, 34, 28-29. 
Coram, R.A. (2014) New insect fossils from the Lower Lias (Lower Jurassic) of West Dorset. Proceedings of the Dorset Archaeological \& Natural History Society, 135, 181-188.

Coram R.A. \& Jepson, J.E. (2012) Fossil insects of the Purbeck Limestone Group of southern England. SIRI Scientific Press, Manchester, i 143 pp.

Fayers, S.R. \& Trewin, N.H. (2005) A hexapod from the Early Devonian Windyfield chert, Rhynie, Scotland. Palaeontology, $48,1117-1130$ https://doi.org/10.1111/j.1475-4983.2005.00501.x

Genise, J.F. (2016) Ichnoentomology. Springer, New York, xxviii $+695 \mathrm{pp}$. https://doi.org/10.1007/978-3-319-28210-7

Haug, C. \& Haug, J.T. (2017) The presumed oldest flying insect: more likely a myriapod? PeerJ, 5, e3402, 1-16. https://doi.org/10.7717/peerj.3402

Hirst, S. \& Maulik, S. (1926) On some arthropod remains from the Rhynie chert (Old Red Sandstone). Geological Magazine, 63, 69-71.

https://doi.org/10.1017/S0016756800083692

Jarzembowski, E.A. (1980) Fossil insects from the Bembridge Marls (Palaeogene) of the Isle of Wight, southern England. Bulletin of the British Museum (Natural History), Geology), 33 (4), 237-293.

Jarzembowski, E.A. (1990) A century plus of fossil insects. Proceedings of the Geologists' Association, 100 (4), 433449.

https://doi.org/10.1016/S0016-7878(89)80019-7

Jarzembowski, E.A. (2011) Insects. In: Batten, D.J. (Ed.), English Wealden fossils. Palaeontological Association Field Guides to Fossils, 14, 138-173 [+ refs].

Jarzembowski, E.A. (2016) Insects Reference Module. Earth Systems and Environmental Sciences, 1, 09735, 1-7. https://doi.org/10.1016/B978-0-12-409548-9.09735-9

Jarzembowski, E.A. (2018) Aust Cliff, Kilmersdon, Lower Writhlington, In: Geological sites of the Bristol Region. BRERC, Bristol, 84-85, 158-160, 171-175.

Jarzembowski, E.A., Cheny, C., Fang, Y. \& Wang, B. (2020) First Mesozoic amphipod crustacean from the Lower Cretaceous of SE England. Cretaceous Research, 112, 1-6, 2 supp. files. https://doi.org/10.1016/j.cretres.2020.104429

Jarzembowski, E.A., Siveter, D.J., Palmer, D. \& Selden, P.A. (2010) Fossil arthropods of Great Britain. Geological Conservation Review Series, vol. 35. Joint Nature Conservation Committee, Peterborough, xvi +294 pp.

Jarzembowski, E.A., Sukatsheva, I.D., Wang, B., Zhang, H. \& Zheng, D. (2016) A tubiculous perspective: new caddisfly cases (Insecta: Trichoptera) from the Lower Cretaceous of southern England and comparison with the Chinese indusifauna. Cretaceous Research, 61, 44-56. https://doi.org/10.1016/j.cretres.2015.12.021
Kania, I., Wang, B. \& Szwedo, J. (2015) Dicranoptycha Osten Sacken, 1860 (Diptera, Limoniidae) from the earliest Upper Cretaceous Burmese amber. Cretaceous Research, 52, 522530. https://doi.org/10.1016/j.cretres.2014.03.002

Li, Y., Chen, J. \& Jarzembowski, E.A. (2021) The first true procercopid (Hemiptera, Cercopoidea) from England. Cretaceous Research, 127, 104933, 1-5. https://doi.org/10.1016/j.cretres.2021.104933

Penney, D. \& Jepson, J.E. (2014) Fossil insects. An introduction to palaeoentomology. SIRI Scientific Press, Manchester, 224 pp.

Perkovsky, E.E., Olmi, M., Müller, P., Guglielmino, A., Jarzembowski, E.A., Capradossi, L. \& Rasnitsyn, A.P. (2021) A review of the fossil Embolemidae (Hymenoptera: Chrysidoidea), with description of seven new species and history of the family. Cretaceous Research, 121, 104708, $1-20$

https://doi.org/10.1016/j.cretres.2020.104708

Radley, J.D. \& Allen, P. (2012a) The Wealden (non-marine Lower Cretaceous) of the Weald Sub-basin, southern England. Proceedings of the Geologists'Association, 123, 245-318. https://doi.org/10.1016/j.pgeola.2012.01.003

Radley, J.D. \& Allen, P. (2012b) The southern English Wealden (nonmarine Lower Cretaceous): overview of palaeoenvironments and palaeoecology. Proceedings of the Geologists'Association, 123, 382-385. https://doi.org/10.1016/j.pgeola.2011.12.005

Ross, A.J. (2010) Insects. In: Lord, A.R. \& Davis, P.G. (Eds), Fossils from the Lower Lias of the Dorset coast. Palaeontological Association Field Guides to Fossils, 13, 276-289 [+ refs].

Ross, A.J. (2011) Cockroaches, In: Batten, D.J. (Ed.), English Wealden fossils. Palaeontological Association Field Guides to Fossils, 14, 15-51 [+ refs].

Selden, P.A. (2021) New spiders (Araneae: Mesothelae) from the Carboniferous of New Mexico and England and a review of Paleozoic Araneae. Bulletin of the American Museum of Natural History, 84, 317-358.

Tihelka, E. (2019) New Mesozoic earwigs from England, with a catalogue of fossil Dermaptera. Proceedings of the Geologists Association, 130, 609-611. https://doi.org/10.1016/j.pgeola.2019.06.003

Tillyard, R.J. (1928) Some remarks on the Devonian fossil insects from the Rhynie chert beds, Old Red Sandstone. Transactions of the Royal Entomological Society of London, 76, 65-71. https://doi.org/10.1111/j.1365-2311.1928.tb01188.x

Toghill, P. (2000) The geology of Britain. Airlife, Marlborough, $192 \mathrm{pp}$.

Williams, M., Benton, M.J. \& Ross, A. (2015) The Strawberry Bank Lagerstätte reveals insights into Early Jurassic life. Journal of the Geological Society of London, 172(6), 683-692. https://doi.org/10.1144/jgs2014-144 